\title{
Effects of preservation methodology on stable isotope compositions of sea stars
}

\author{
Le Bourg Baptiste ${ }^{1, *}$, Lepoint Gilles ${ }^{1}$, Michel Loic ${ }^{1}$
}

${ }^{1}$ Laboratory of Oceanology, Freshwater and Oceanic Sciences Unit of reSearch (FOCUS)University of Liège 4000 Liège ,Belgium

*Corresponding author :Baptiste Le Bourg, email address : blebourg@uliege.be

\begin{abstract}
:
Rationale

Stable isotope analysis is used to investigate the trophic ecology of organisms and, in order to use samples from archived collections, and it is important to know whether preservation methods alter the results. This study investigates the long-term effects of four preservation methods on sea stars isotopic composition and isotopic niche parameters.
\end{abstract}

Methods

We assessed effects of preservation method (freezing, drying, formaldehyde, ethanol) and duration $(0,1$, $3,6,9,12$ and 24 months) on the stable isotope ratios of carbon, nitrogen and sulfur of sea star tissues. Isotopic ratios were measured using CF-EA-IRMS. We also monitored the evolution of commonly used ecological metrics (isotopic niche parameters) throughout the experiment.

Results

Clear changes of $\delta 13 \mathrm{C}$ values were observed for samples stored in formaldehyde and ethanol. None of the preservation methods had significant or consistent effects on $\delta 15 \mathrm{~N}$ values. Formaldehyde induced a decrease of $\delta 34 \mathrm{~S}$ values. All these changes could be mitigated using correction factors. Isotopic niches parameters slightly changed over time when computed with $\delta 13 \mathrm{C}$ and $\delta 15 \mathrm{~N}$ values, but inconsistent variations occurred when computed with $\delta 13 \mathrm{C}$ and $\delta 34 \mathrm{~S}$ values.

Conclusions

Overall, these results show that preservation may affect the stable isotope ratios of sea stars. Correction factors can be used to mitigate the effects of the preservation method on stable isotope ratios. Isotopic niches parameters are overall unchanged. Consequently, in most cases, museum samples are suitable to calculate isotopic niche parameters. 


\section{Introduction}

Stable isotope analysis (SIA) is now a common tool for food web studies. Carbon isotopic compositions $\left({ }^{13} \mathrm{C}:{ }^{12} \mathrm{C} ; \delta^{13} \mathrm{C}\right.$ values $)$ are generally used to determine the origin of primary sources of carbon in food webs or feeding areas ${ }^{1,2}$ because of the differences of stable isotope composition between the different types of primary producers (i.e. phytoplankton, phytobenthos, terrestrial organic matter...) and the low ${ }^{13} \mathrm{C}$-enrichment in organisms relative to their diet ${ }^{2,3}$. Nitrogen isotopic compositions $\left({ }^{15} \mathrm{~N}:{ }^{14} \mathrm{~N} ; \delta^{15} \mathrm{~N}\right.$ values) are used to assess nitrogen sources and to estimate the trophic level of consumers, as organisms are generally enriched in ${ }^{15} \mathrm{~N}$ relative to their diet, resulting in increasing $\delta^{15} \mathrm{~N}$ values with trophic level ${ }^{2,4}$. Similarly to $\delta^{13} \mathrm{C}$ values, sulfur isotopic compositions $\left({ }^{34} \mathrm{~S}:{ }^{32} \mathrm{~S} ; \delta^{34} \mathrm{~S}\right.$ values $)$ are used in studies on marine food webs to refine the discrimination between primary producers, and notably of benthic and pelagic sources, thanks to the differences of $\delta^{34} S$ values between seawater sulphates and sediment sulphides ${ }^{5,6,7}$.

Stable isotope ratios of samples from museum collections may represent a readily accessible source of information for food web studies. They can notably help to fill gaps in our knowledge of the ecology of species coming from data-poor regions or ecosystems. Samples from museum collections were often collected during periods when environmental conditions were different and usually more pristine than today, and thus may be used to study past trophic ecology of organisms. Unfortunately, preservative fluids are known to alter stable isotopes ratios in samples ${ }^{8,9,10}$. Furthermore, the impacts of preservation methods are taxon-specific ${ }^{10,11}$ and studies of these impacts on particular taxa are necessary.

Teleosts is the taxon where the effects of preservation methodology on stable isotope ratios have been most studied $8,12,13,14,15,16$. The influence of preservation methodology on stable isotope ratios has also been investigated in various other taxa such as elasmobranchs ${ }^{17,18}$, chelonians ${ }^{19}$, birds $^{20}$, marine ${ }^{21}$ and terrestrial mammals ${ }^{22}$ and even photosynthetic organisms ${ }^{8,11,23}$. The influence of preservation methods on stable isotope ratios has also been investigated in several invertebrate taxa such as cnidarians ${ }^{11,24}$, molluscs $8,10,11,25,26$, polychaetes ${ }^{10,26}$, sipunculid ${ }^{10}$ and aquatic $^{12,14,27}$ and terrestrial arthropods $^{28,29}$. Nevertheless, the influence of preservation method on stable isotope ratios has been poorly investigated for several taxa. This is the case for echinoderms, on which the effects of preservation on stable isotope ratios have only been studied in one holothuroid species $^{10}$. 
With some exceptions ${ }^{23,24,25,30}$, most of these studies agree that freezing and drying do not alter stable isotope ratios and that preservation or fixation of organisms with formaldehyde induces a negative shift of $\delta^{13} \mathrm{C}$ values. However, more conflicting results were reported on the impact of ethanol on $\delta^{13} \mathrm{C}$ values, with either no significant changes or increasing $\delta^{13} \mathrm{C}$ values being observed ${ }^{8,9,10}$. The study of the impact of formaldehyde and ethanol on $\delta^{15} \mathrm{~N}$ values also led to conflicting results (Table 1). Contrary to $\delta^{13} \mathrm{C}$ and $\delta^{15} \mathrm{~N}$ values, the impact of preservation on $\delta^{34} \mathrm{~S}$ values has been poorly investigated so far (but $\mathrm{see}^{13,22}$ ).

The increasing use of SIA also led to the development of new ecological metrics and models to assess between and/or within-group trophic diversity and variability ${ }^{31,32,33}$, source partitioning ${ }^{34}$ or trophic levels of organisms ${ }^{35}$. All these approaches take into account the isotopic variability of consumers (intra or intergroup comparisons) and allow us to calculate diverse ecologically meaningful isotopic metrics. However, to date only one study has investigated the impact of preservation on mixing model performance ${ }^{36}$. To the best of our knowledge, the influence of preservation method on isotopic niche modelling has never been tested despite these metrics being increasingly used.

Among echinoderms, sea stars (class: Asteroidea) are usually predatory organisms. With the exception of species from the Paxillosida order, that represent roughly $20 \%$ of extant species, sea stars are known to revert their stomach in order to preliminary digest their prey externally. As a result, stomach content analyses are complicated for this taxonomic group although some authors have been able to use this method ${ }^{37,38,39}$. Stable isotope ratios are therefore an interesting tool to investigate the trophic role of sea stars in ecosystems and the impact of preservation methods on stable isotope ratios in sea star tissues should be investigated.

In this context, the aim of this study was to determine whether chemically preserved sea star samples, such as those stored in museum collections, were suitable for trophic ecology studies. To achieve this goal, we 1) experimentally assessed the modifications of stable isotope ratios in sea star tissues preserved up to two years with different methods (freezing, drying, formaldehyde, ethanol), 2) attempted to determine if correction factors could be used to correct eventual modifications, and 3) investigated the influence of these modifications on the resulting isotopic niches and associated parameters ${ }^{33}$.

\section{Material and methods}

Sampling and stable isotope analysis 
Sea stars of the species Marthasterias glacialis $(n=20)$ were collected in the Atlantic Ocean, near the Roscoff biological station (Brittany, France) in April 2016. The sea stars were maintained alive until their transfer to the laboratory. For each sea star, the arms were separated from the central disc and internal organs were removed in each arm. The first arm of each sea star was immediately dried and homogenised into powder $\left(\mathrm{T}_{0}\right)$. The other arms were randomly assigned to each preservation method (freezing, drying, formaldehyde, ethanol) and cut into six sections, each section being randomly assigned to a time of analysis $(1,3,6,9,12$ and 24 months; $n=20$ samples per method and per time of analysis). Each arm section was individually either frozen at $-28^{\circ} \mathrm{C}$, oven dried, or preserved in $3.7 \%$ formaldehyde or $99.8 \%$ ethanol. At the assigned date of analysis, with the exception of the already dried samples, the arm sections were rinsed with distilled water and dried. All samples were then ground into powder for homogenisation using a mixer mill (MM301, Retsch, Haan, Germany), prior to stable isotope analyses

Carbonates in the endoskeleton of sea stars are more ${ }^{13} \mathrm{C}$-enriched than other tissue components ${ }^{3}$. Consequently, carbonates were removed from the samples by exposing subsamples to $37 \%$ hydrochloric acid vapour for 48 hours $^{40}$. The subsamples were then precisely weighed ( $c a 2.5-3 \mathrm{mg}$ ) in $5 \times 4 \mathrm{~mm}$ tin cups with $c a 3 \mathrm{mg}$ of tungsten trioxide, and analysed with an elemental analyser (vario MICRO Cube, Elementar, Hanau, Germany) coupled to a continuous-flow isotope-ratio mass spectrometer (IsoPrime100, Elementar UK, Cheadle, UK). The stable isotope ratios of carbon, nitrogen and sulfur were expressed in the $\delta$ notation $\left(\delta^{13} \mathrm{C}, \delta^{15} \mathrm{~N}\right.$ and $\delta^{34} \mathrm{~S}$ values, respectively $\left.{ }^{41}\right)$ in \%o relative to international references (Vienna Pee Dee Belemnite for $\delta^{13} \mathrm{C}$ values, $\mathrm{N}_{2}$ in atmospheric air for $\delta^{15} \mathrm{~N}$ values and Canyon Diablo troilite for $\delta^{34} S$ values). Certified reference materials from the International Atomic Energy Agency (IAEA, Vienna, Austria), IAEA N-1 (ammonium sulphate; $\delta^{15} \mathrm{~N}=$ $0.4 \pm 0.2 \%$ ), IAEA C-6 (sucrose; $\delta^{13} \mathrm{C}=-10.8 \pm 0.5 \%$ ) and IAEA S-1 (silver sulphide; $\delta^{34} \mathrm{~S}$ $=-0.3 \%$ ) were used as primary standards. Sulfanilic acid (Sigma-Aldrich, Overijse, Belgium; $\delta^{13} \mathrm{C}=-25.6 \pm 0.4 \% ; \delta^{15} \mathrm{~N}=-0.1 \pm 0.4 \%$; $\delta^{34} \mathrm{~S}=5.9 \pm 0.5 \%$; means $\pm \mathrm{SD}$ ) and one of the samples (randomly selected; $\delta^{13} \mathrm{C}=-15.1 \pm 0.3 \%$, $\delta^{15} \mathrm{~N}=12.3 \pm 0.2 \%$; $\delta^{34} \mathrm{~S}=$ $16.9 \pm 0.8 \%$ ) were used as secondary analytical standard and replicate, respectively. $\mathrm{T}_{0}$ samples were analysed four times, i.e. once per method, in order to have a balanced data design. Elemental data are expressed as a ratio between the concentrations of $\mathrm{C}$ and $\mathrm{N}(\mathrm{C} / \mathrm{N}$ mass ratio), measured relative to dry mass (\%DM). 


\section{Data analysis}

All the data analyses were performed using R 3.3.3 ${ }^{42}$.

Two-way repeated measures analyses of variance (ANOVA) were performed on $\delta^{13} \mathrm{C}$, $\delta^{15} \mathrm{~N}$ and $\delta^{34} \mathrm{~S}$ values and on $\mathrm{C} / \mathrm{N}$ ratios to assess the effects of preservation methods and time of preservation on those parameters. In case of significant differences, subsequent one-way repeated measures ANOVA were performed in each preservation method to assess the effect of time of preservation on $\delta^{13} \mathrm{C}, \delta^{15} \mathrm{~N}$ and $\delta^{34} \mathrm{~S}$ values and on $\mathrm{C} / \mathrm{N}$ ratios. In case of significant differences, pairwise comparisons with Bonferroni correction ${ }^{43}$ were computed to compare $\delta^{13} \mathrm{C}, \delta^{15} \mathrm{~N}$ and $\delta^{34} \mathrm{~S}$ values between $\mathrm{T}_{0}$ and preserved samples at each time to determine when preservation is altering stable isotopes ratios. Normality of residuals was checked for all models using Q-Q plots and Shapiro tests. In case of a consistent effect of preservation time, i.e. a significant change of $\delta^{13} \mathrm{C}, \delta^{15} \mathrm{~N}$ or $\delta^{34} \mathrm{~S}$ values at a given time of preservation that still occurs after this time, correction factors were computed. To do so, differences of mean $\delta^{13} \mathrm{C}$, $\delta^{15} \mathrm{~N}$ or $\delta^{34} \mathrm{~S}$ values between $\mathrm{T}_{0}$ samples and significantly different preserved samples were calculated. One-way repeated measures ANOVAs and subsequent post-hoc analyses were then performed to compare the differences between corrected $\delta^{13} \mathrm{C}, \delta^{15} \mathrm{~N}$ or $\delta^{34} \mathrm{~S}$ values and non-corrected $\delta^{13} \mathrm{C}, \delta^{15} \mathrm{~N}$ or $\delta^{34} \mathrm{~S}$ values from previous times of analysis and $\mathrm{T}_{0}$ samples.

For each preservation method and for each time of analysis, standard ellipses representing isotopic niches (see Figure 1 in Jackson et $\mathrm{al}^{33}$; Reid et $\mathrm{al}^{44}$ for details) were computed using the $\delta^{13} \mathrm{C}$ and $\delta^{15} \mathrm{~N}$ values, or the $\delta^{13} \mathrm{C}$ and $\delta^{34} \mathrm{~S}$ values and the temporal evolution of the following parameters was investigated: lengths of the semi-major $\left(a_{c}\right)$ and semi-minor $\left(b_{c}\right)$ axes (sample size corrected), angle $(\theta)$ of the semi-major axis with the $\mathrm{x}$ axis, and the eccentricity $(\varepsilon)$ of the ellipse ( $\varepsilon=0$ means that the "ellipse" is a circle i.e. $a_{c}=b_{c}$ ). Finally, sample size corrected $\left(\mathrm{SEA}_{\mathrm{c}}\right)$ and Bayesian (based on $5.10^{5}$ successive iterations; $\mathrm{SEA}_{\mathrm{B}}$ ) estimates of the standard ellipse area (SEA) were computed with the SIBER package ${ }^{33}$. For each method of preservation, $\mathrm{SEA}_{\mathrm{B}}$ was directly compared with the $\mathrm{SEA}_{\mathrm{B}}$ of $\mathrm{T}_{0}$ samples by assessing the proportion of estimated SEA computed by the SIBER package for which the SEA of the preserved samples were higher or lower than the SEA of $\mathrm{T}_{0}$ samples. If this proportion of higher or lower SEA exceeded 95\%, the SEAB values of fresh and preserved samples were considered as being different.

\section{Results}


Significant influences of the preservation method $\left(\mathrm{F}_{3,57}=113.338, \mathrm{P}<0.001\right)$ and of its interaction with the time of analysis $\left(\mathrm{F}_{18,342}=6.718, \mathrm{P}<0.001\right)$ were observed on $\delta^{13} \mathrm{C}$ values. Subsequent ANOVAs performed in each preservation method revealed different effects of preservation on $\delta^{13} \mathrm{C}$ values. The $\delta^{13} \mathrm{C}$ values are strongly altered by formaldehyde preservation $\left(\mathrm{F}_{6,114}=14.360, \mathrm{P}<0.001\right)$ : the values immediately decreased at the first month of preservation and then remained stable throughout the experiment (Figure 1A). The difference of $\delta^{13} \mathrm{C}$ values between $\mathrm{T}_{0}$ samples and preserved samples was $-0.8 \pm 0.5 \%$. Consequently, adding $0.8 \%$ to $\delta^{13} \mathrm{C}$ values of samples preserved in formaldehyde suppressed significant differences in the $\delta^{13} \mathrm{C}$ values between $\mathrm{T}_{0}$ samples and preserved samples whatever the treatment time $\left(\mathrm{F}_{6,114}=0.374, \mathrm{P}=0.894\right)$. Ethanol had a significant effect on $\delta^{13} \mathrm{C}$ values $\left(\mathrm{F}_{6,114}=5.701, \mathrm{P}<0.001\right)$, which increased through time until reaching an asymptote (Figure 1A). Subsequent pairwise comparisons with Bonferroni correction showed that the significant change of $\delta^{13} \mathrm{C}$ values occurred at 9 months of preservation and was still present at 12 and 24 months of preservation (Table S1, supporting information). The difference of $\delta^{13} \mathrm{C}$ values between $\mathrm{T}_{0}$ samples and preserved samples after 9 months was 0.6 $\pm 0.5 \%$. Adding $-0.6 \%$ from $\delta^{13} \mathrm{C}$ values of samples preserved in ethanol after 9 months suppressed significant differences in the $\delta^{13} \mathrm{C}$ values between the $\mathrm{T}_{0}$ samples and the preserved samples but some differences appeared between the ime of analysis $\left(\mathrm{F}_{6,114}=4.532\right.$, $\mathrm{P}<0.001)$.

Significant influences of the preservation method $\left(\mathrm{F}_{3,57}=22.848, \mathrm{P}<0.001\right)$ and of its interaction with the time of analysis $\left(\mathrm{F}_{18,342}=2.986, \mathrm{P}<0.001\right)$ were observed on $\delta^{15} \mathrm{~N}$ values. Subsequent ANOVAs performed in each preservation method revealed inconsistent effects of drying on $\delta^{15} \mathrm{~N}$ values $\left(\mathrm{F}_{6,114}=4.436, \mathrm{P}<0.001\right.$, Figure $\left.1 \mathrm{~B}\right)$ as there was no significant differences in the $\delta^{15} \mathrm{~N}$ values between $\mathrm{T}_{0}$ and other times of analysis, but some differences between the times of analysis (Table S1, supporting information). Furthermore, storage in formaldehyde $\left(\mathrm{F}_{6,114}=2.136, \mathrm{P}=0.055\right)$ and ethanol $\left(\mathrm{F}_{6,114}=2.178, \mathrm{P}=0.050\right)$ appeared to have a marginally significant effect on $\delta^{15} \mathrm{~N}$ values (Figure 1B).

The results of the two-way repeated measures ANOVA showed an influence of preservation method $\left(\mathrm{F}_{3,57}=87.415, \mathrm{P}<0.001\right)$, time of analysis $\left(\mathrm{F}_{6,114}=7.371, \mathrm{P}<0.001\right)$ and of their interaction $\left(\mathrm{F}_{18,342}=6.617, \mathrm{P}<0.001\right)$ on $\delta^{34} \mathrm{~S}$ values. The $\delta^{34} \mathrm{~S}$ values changed inconsistently in frozen samples $\left(\mathrm{F}_{6,114}=3.168, \mathrm{P}=0.007\right)$, with samples stored for 3 and 12 months having significantly different $\delta^{34} S$ values (Figure 1C; Table S1, supporting information). Inconsistent changes of $\delta^{34} \mathrm{~S}$ values also occurred in dried samples $\left(\mathrm{F}_{6,114}=\right.$ 
7.255, $\mathrm{P}<0.001$ ), with significant deviance from the $\delta^{34} \mathrm{~S}$ values of $\mathrm{T}_{0}$ samples occurring only at 3 months of preservation but not earlier or later (Figure 1C). The $\delta^{34} \mathrm{~S}$ values changed significantly in samples stored in formaldehyde $\left(\mathrm{F}_{6,114}=11.950, \mathrm{P}<0.001\right)$ : the $\delta^{34} \mathrm{~S}$ values of preserved samples were significantly lower than those of $\mathrm{T}_{0}$ samples for all time periods, with the mean shift between $\mathrm{T}_{0}$ and those times of analysis being $-1.5 \pm 1.2 \%$ (Figure 1C). Adding $1.5 \%$ to the $\delta^{34} \mathrm{~S}$ values of samples preserved in formaldehyde suppressed any significant differences between times of analysis despite the ANOVA remaining significant, but with a very low $\mathrm{F}$ value $\left(\mathrm{F}_{6,114}=2.327, \mathrm{P}=0.037\right.$; Table $\mathrm{S} 1$, supporting information $)$. A significant influence of ethanol preservation on $\delta^{34} \mathrm{~S}$ values was observed $\left(\mathrm{F}_{6,114}=2.659, \mathrm{P}=\right.$ 0.018 ) but different $\delta^{34} \mathrm{~S}$ values could be seen only between $\mathrm{T}_{0}$ samples and samples stored for 24 months in the post-hoc analysis (Figure 1C; Table S1, supporting information). The mean shift of $\delta^{34} \mathrm{~S}$ values between $\mathrm{T}_{0}$ samples and samples stored in ethanol for 24 months was $-0.7 \pm 1.0 \%$. Adding $0.7 \%$ to the $\delta^{34} \mathrm{~S}$ values of samples preserved for 24 months in ethanol suppressed the slightly significant difference in the $\delta^{34} \mathrm{~S}$ values between them and $\mathrm{T}_{0}$ samples. However, this correction created differences between the $\delta^{34} S$ values of samples stored for 24 months and other times of analysis (Table S1, supporting information), and caused an increase of the ANOVA's F value $\left(\mathrm{F}_{6,114}=4.323, \mathrm{P}<0.001\right)$.

Significant influences of preservation method $\left(\mathrm{F}_{3,57}=162.972, \mathrm{P}<0.001\right)$, time of analysis $\left(\mathrm{F}_{6,114}=2.641, \mathrm{P}=0.020\right)$ and of their interaction $\left(\mathrm{F}_{18,342}=10.209, \mathrm{P}<0.001\right)$ were observed on $\mathrm{C} / \mathrm{N}$ ratios. Subsequent ANOVAs and post-hoc analyses in each preservation method showed marginal effects of freezing on $\mathrm{C} / \mathrm{N}$ ratios $\left(\mathrm{F}_{6,114}=2.252, \mathrm{P}=0.043\right)$ and pairwise comparisons with Bonferroni correction did not detect any significant change in $\mathrm{C} / \mathrm{N}$ ratios (Table $\mathrm{S} 1$, supporting information). Storage in formaldehyde $\left(\mathrm{F}_{6,114}=3.948, \mathrm{P}=0.001\right)$ and ethanol $\left(\mathrm{F}_{6,114}=20.740, \mathrm{P}<0.001\right.$, Figure $\left.1 \mathrm{D}\right)$ induced changes of $\mathrm{C} / \mathrm{N}$ ratios. For samples stored in formaldehyde, higher $\mathrm{C} / \mathrm{N}$ ratios were observed at 6 months of preservation than in $\mathrm{T}_{0}$ samples (Table $\mathrm{S} 1$, supporting information). For ethanol, $\mathrm{C} / \mathrm{N}$ ratios immediately decreased at the first month of preservation and then remained stable throughout the experiment (Table S1, supporting information). In this case, the difference of $\mathrm{C} / \mathrm{N}$ ratios between $\mathrm{T}_{0}$ samples and preserved samples was $0.22 \pm 0.10$.

When computed with $\delta^{13} \mathrm{C}$ and $\delta^{15} \mathrm{~N}$ values, the ellipse parameters changed little and inconsistently and, as a result, they were similar at the beginning and at the end of the experiment (Figure S1, supporting information). Changes of $\mathrm{SEA}_{\mathrm{B}}$ occurred between $\mathrm{T}_{0}$ samples and each time of preservation for samples stored dried or ethanol (Figure 2). For 
samples stored dried, the SEA $A_{B}$ the values or samples stored for 3 months was higher than for $\mathrm{T}_{0}$ ones (Figure $2 \mathrm{~B}$ ). For samples stored in ethanol, the $\mathrm{SEA}_{\mathrm{B}}$ values for samples stored during 1 month and 24 months were higher than for the $\mathrm{T}_{0}$ ones (Figure 2D). Yet, these changes did not occur consistently for other times of preservation. The overlap between $\mathrm{T}_{0}$ ellipses and ellipses for other times of analysis appeared to be weak in samples stored in formaldehyde and in ethanol (Figure 3 ) because of the shift of mean $\delta^{13} \mathrm{C}$ values previously observed for these two preservative fluids (Figure 1A).

When the standard ellipses were computed with $\delta^{13} \mathrm{C}$ and $\delta^{34} \mathrm{~S}$ values, more important and more inconsistent changes of the parameters occurred (Figure S2, supporting information). Indeed, changes of the length of ellipses' axes frequently exceeded $0.1 \%$ (Figures S2A and S2B, supporting information). In all methods, the angles of the ellipses were the opposite of the angle of ellipses from $\mathrm{T}_{0}$ samples at least at one time of analysis, and even the angle of ellipses from $\mathrm{T}_{0}$ samples were different between preservation methods (Figure S2C, supporting information), resulting in inverted orientation of the ellipses. Changes of the SEA did not occur during the experiment (Figure 4). The absence of overlap between the $\mathrm{T}_{0}$ ellipses and ellipses for other times of analysis that appeared in samples stored in formaldehyde, as well as the weak overlap that appeared in ethanol (Figure 5) is mostly the result of the shift of the mean of both the $\delta^{13} \mathrm{C}$ and the $\delta^{34} \mathrm{~S}$ values previously observed for these two preservative fluids (Figures 1A and 1C).

\section{Discussion}

Contrasting effect of preservation on $\delta^{13} \mathrm{C}$ values in sea stars were observed. Freezing and drying had no or marginal effect on $\delta^{13} \mathrm{C}$ values throughout time, while formaldehyde induced rapid decrease of $-0.8 \pm 0.5 \%$ for $\delta^{13} \mathrm{C}$ values during the first month of preservation. Those values were subsequently stable throughout the experiment. Decrease followed by stability of $\delta^{13} \mathrm{C}$ values was frequently observed for organisms stored in formaldehyde $\mathrm{e}^{8,9,36}$. However, the time at which the change of $\delta^{13} \mathrm{C}$ values occurs may differ, going from several weeks ${ }^{8,9,36}$ to one year ${ }^{10}$. Furthermore, the decrease of $\delta^{13} \mathrm{C}$ values that we observed is usually lower than the previously reported shift induced by formaldehyde. After the initial change, the $\delta^{13} \mathrm{C}$ values seem to remain stable during longer term preservation ${ }^{27}$. Protein lysis ${ }^{9}$ and/or integration of $\mathrm{C}$ from the preservative liquid into the samples ${ }^{8,9,13}$ are proposed mechanisms to explain this phenomenon. Increasing $\mathrm{C} / \mathrm{N}$ ratios in samples stored in formaldehyde ${ }^{10,14}$ support this hypothesis, and higher $\mathrm{C} / \mathrm{N}$ ratios were observed at 6 months of preservation in 
our experiment. Considering that $\delta^{13} \mathrm{C}$ values are not further altered by formaldehyde following the initial change, we recommend using a correction factor for $\delta^{13} \mathrm{C}$ values of sea star samples that have been in formaldehyde for more than one month no matter how long they have been preserved. Indeed, adding $0.8 \%$ to $\delta^{13} \mathrm{C}$ values of samples stored in formaldehyde resulted in similar carbon isotopic ratios for fresh and preserved samples in our experiment. Testing of the influence of ethanol on isotopic ratios has led to conflicting results: either stable $e^{9,10}$ or increasing ${ }^{8,9,10,36} \delta^{13} \mathrm{C}$ values in samples were previously observed. In Marthasterias glacialis, a gradual increase of $\delta^{13} \mathrm{C}$ values was observed. This increase became significant after 9 months of preservation where it went up to $0.6 \pm 0.5 \%$. This phenomenon may be explained by the extraction of lipids by ethanol ${ }^{45}$, as highlighted by the decrease of $\mathrm{C} / \mathrm{N}$ ratios that we observed for samples stored in ethanol. Long-term preservation in ethanol could also induce leaching of other compounds such as amino acids ${ }^{45}$. These results suggest that using a correction factor for $\delta^{13} \mathrm{C}$ values of ethanol-preserved sea stars stored for more than 9 months is advised. Indeed, adding $-0.6 \%$ to $\delta^{13} \mathrm{C}$ values of samples stored for more than 9 months in ethanol suppressed significant differences between fresh and preserved samples in our experiment.

No major $\delta^{15} \mathrm{~N}$ changes were recorded for any of the preservation methods. Freezing, or the use of formaldehyde and ethanol did not lead to any significant differences. Some differences were present in the drying experiment, but these changes were not consistent over time and occurred between times of analysis and not between $\delta^{15} \mathrm{~N}$ values of dried samples and those of $\mathrm{T}_{0}$ samples. Seasonal variations of temperature and humidity in the storage room could contribute to this inconsistent variability on $\delta^{15} \mathrm{~N}$ values throughout the experiment. Conflicting results have been reported on the impact of formaldehyde and ethanol on $\delta^{15} \mathrm{~N}$ values $^{9,10,14,27}$, suggesting that $\delta^{15} \mathrm{~N}$ values are generally not affected by preservation.

In this study, the $\delta^{34} \mathrm{~S}$ values of sea stars was much more variable than the other isotopic ratios. The standard deviation on a sea star sample randomly chosen as sa econdary analytical standard was $0.3 \%$ for $\delta^{13} \mathrm{C}$ values, $0.2 \%$ for $\delta^{15} \mathrm{~N}$ values, but $0.8 \%$ for $\delta^{34} \mathrm{~S}$ values. This could be caused by a higher natural variability of this parameter in sea stars, but also because of a higher analytical error, as sea star tissues contain low amounts of total sulfur. Our results therefore have to be interpreted with caution. Nevertheless, they suggest that formaldehyde, and possibly ethanol reduce $\delta^{34} S$ values. In formaldehyde, the $\delta^{34} S$ values of preserved samples were significantly lower than those of fresh samples after the first month of preservation. However, adding a correction factor of $1.5 \%$ to the $\delta^{34} S$ values of 
preserved samples in our experiment allowed the effects of preservation to be corrected, despite the within-treatment error being close to the average $\delta^{34} \mathrm{~S}$ value shift $(-1.5 \pm 1.2 \%$ o) A weaker and slower decrease of $\delta^{34} \mathrm{~S}$ values occurred in samples stored in ethanol, with the decrease being slightly significant only at 24 months of preservation. By comparison, previous studies observed different effects of preservative fluids on $\delta^{34} \mathrm{~S}$ values. Indeed, an increase of mean $\delta^{34} \mathrm{~S}$ values was observed in teleosts fixed with formaldehyde and then stored in ethanol $(0.8 \pm 0.5 \%)^{13}$ while no effects of ethanol preservation were observed on $\delta^{34} \mathrm{~S}$ values in bear tissues ${ }^{22}$. Our results suggest that a using a correction factor to mitigate the effects of ethanol on $\delta^{34} \mathrm{~S}$ values is not adequate. The within-treatment error was indeed higher than the average $\delta^{34} \mathrm{~S}$ value shift $(-0.7 \pm 1.0 \%$ ). Moreover, although using this correction factor prevented significant differences between the $\delta^{34} \mathrm{~S}$ values of $\mathrm{T}_{0}$ samples and those of samples stored for 24 months, it created previously non-existing significant differences between samples stored for 24 months and several other times of analysis. Furthermore, use of this correction factor seemed to increase the overall inter-treatment variability, as shown by the higher ANOVA F value. Considering these results, we do not advise using correction factors for the $\delta^{34} \mathrm{~S}$ values of star tissues preserved in ethanol. For samples stored frozen or dried, no significant differences of $\delta^{34} \mathrm{~S}$ values between fresh and preserved samples were observed.

The ellipse parameters computed with $\delta^{13} \mathrm{C}$ and $\delta^{15} \mathrm{~N}$ values were slightly affected by preservation, resulting in estimation of $\mathrm{SEA}_{\mathrm{B}}$ being inconsistently affected in samples stored dried or in ethanol while not affected by freezing and formaldehyde. Consequently, preservation does not seem to be an obstacle to the study of isotopic niches computed with $\delta^{13} \mathrm{C}$ and $\delta^{15} \mathrm{~N}$ values, and thus trophic niches, of sea stars using ellipses-based methods and the lack of overlap between fresh and preserved samples are more likely to be the result of the changes of mean $\delta^{13} \mathrm{C}$ values. By contrast, inconsistent variations of ellipse parameters occurred when computed with $\delta^{13} \mathrm{C}$ and $\delta^{34} \mathrm{~S}$ values, because of both the preservation induced changes of $\delta^{34} \mathrm{~S}$ values and the higher variability of this parameter. While these results need to be further tested both in sea stars and in other taxa, caution is advised when dealing with sulfur isotopic ratios of fluid-preserved samples.

\section{Conclusions}

Our results show that the preservation method has to be taken into account when 
determining stable isotope ratios of carbon in sea stars. Freezing and drying appear to be the best preservation methods (Table 2). Freezing did not induce changes of $\delta^{13} \mathrm{C}, \delta^{15} \mathrm{~N}$ and $\delta^{34} \mathrm{~S}$ values, or ellipse parameters when computed with $\delta^{13} \mathrm{C}$ and $\delta^{15} \mathrm{~N}$ values. This result is in accordance with previous studies where freezing is generally considered as one of the best preservation methods with no effect on stable isotope ratios being observed ${ }^{8,12,23,46}$, although some exceptions occurred ${ }^{25,29,30}$. Drying appeared to have no effect on $\delta^{13} \mathrm{C}$ values and minimal effect on $\delta^{34} \mathrm{~S}$ values but long-term drying could induce inconsistent variability of $\delta^{15} \mathrm{~N}$ values. While formaldehyde induced a sharp decrease of $-0.8 \pm 0.5 \%$ in $\delta^{13} \mathrm{C}$ values during the first month of preservation, the $\delta^{13} \mathrm{C}$ values remained stable once altered and it is thus possible to correct the effects of preservation with a correction factor, no matter how long sea stars were stored in formaldehyde. A decrease and then stability of $\delta^{13} \mathrm{C}$ values in samples stored in formaldehyde was previously observed ${ }^{8,9,36}$, including at decadal scale ${ }^{27}$. Furthermore, $\delta^{15} \mathrm{~N}$ values and ellipse parameters computed with $\delta^{13} \mathrm{C}$ and $\delta^{15} \mathrm{~N}$ values did not appear to be strongly affected by preservation in formaldehyde, and the change of the position of the ellipse is the result of the changes of mean $\delta^{13} \mathrm{C}$ values. $\delta^{34} \mathrm{~S}$ values decreased in samples stored in formaldehyde but this change can be corrected. The results showed that $\delta^{13} \mathrm{C}$ values are affected by storage in ethanol, probably because of lipid extraction. Considering the significant increase of $\delta^{13} \mathrm{C}$ values observed in other taxa ${ }^{8,9,10}$, some knowledge on the lipid (or other ethanol-soluble compounds) content of samples may be beneficial before analysing sea star samples stored in ethanol. By contrast, $\delta^{15} \mathrm{~N}$ values were not affected by ethanol preservation. Furthermore, long-term preservation in ethanol appeared to induce a decrease of $\delta^{34} S$ values. However, using a correction for $\delta^{34} S$ values in sea star samples stored in ethanol is not advised. Overall, the four preservation methods tested in this experiment minimally impacted stable isotope ratios or induced impacts that can be dealt with by using correction factors. Such results tend to indicate that sea stars samples stored in preservative fluids and, thus, those stored by museums, may be used for trophic ecology studies using stable isotope ratios.

\section{Acknowledgement}

We would like to thank Pierre Balthasart (Collectif des Enseignements en Biologie, University of Liège) and Véronique Goosse (Département de Biologie, Ecologie et Evolution, University of Liège) for providing the sea stars. This research was funded by the Belgian Science Policy Office (BELSPO) through the vERSO and RECTO projects 
(www.rectoversoprojects.be, contract nr. BR/132/A1/vERSO and BR/154/A1/RECTO). B.L.B. has received a PhD scholarship from the Belgian Fund for Research Training in Industry and Agriculture (FRIA). G.L. is a Research Associate at the Belgian Fund for Scientific Research (F.R.S.-FNRS). We thank two anonymous referees for their helpful comments. This paper is the MARE publication number X.

\section{Data availability}

The raw data underlying this article are freely available at the PANGAEA database (https://www.pangaea.de/) at XXXXX.

\section{References}

1 Hobson KA. Tracing origins and migration of wildlife using stable isotopes: a review. Oecologia. 1999;120:314-326. doi:10.1007/s004420050865

2 Michener RH, Kaufman L. Stable isotopes ratios as tracers in marine food webs: an update. In: Michener R, Lajtha K eds. Stable isotopes in ecology and environmental science. Blackwell Publishing, 2007:238-282. doi:10.1002/9780470691854.ch9

3 DeNiro MJ, Epstein S. Influence of diet on the distribution of carbon isotopes in animals. Geochim Cosmochim Acta. 1978;42:495-506. doi:10.1016/0016-7037(78)90199-0

4 DeNiro MJ, Epstein S. Influence of diet on the distribution of nitrogen isotopes in animals. Geochim Cosmochim Acta. 1981;45:341-351. doi:10.1016/0016-7037(81)90244-1

5 Fry B, Scalan RS, Winters JK, Parker PL. Sulphur uptake by salt grasses, mangroves, and seagrasses in anaerobic sediments. Geochim Cosmochim Acta. 1982;46:1121-1124. doi:10.1016/0016-7037(82)90063-1

6 Machás R, Santos R. Sources of organic matter in Ria Formosa revealed by stable isotope analysis. Acta Oecol. 1999;20:463-469. doi:10.1016/S1146-609X(99)00122-8

7 Connolly RM, Guest MA, Melville AJ, Oakes JM. Sulfur stable isotopes separate producers in marine food-web analysis. Oecologia. 2004;138:161-167. doi:10.1007/s00442-0031415-0

8 Kaehler S, Pakhomov EA. Effects of storage and preservation on the $\delta^{13} \mathrm{C}$ and $\delta^{15} \mathrm{~N}$ signatures of selected marine organisms. Mar Ecol Prog Ser. 2001;219:299-304. doi:10.3354/meps219299

9 Sarakinos HC, Johnson ML, Vander Zanden MJ. A synthesis of tissue-preservation effects on carbon and nitrogen stable isotope signatures. Can J Zool. 2002;80:381-387. 
doi:10.1139/z02-007

10 Fanelli E, Cartes JE, Papiol V, Rumolo P, Sprovieri M. Effects of preservation on the $\delta^{13} \mathrm{C}$ and $\delta^{15} \mathrm{~N}$ values of deep sea macrofauna. J Exp Mar Biol Ecol. 2010;395:93-97. doi:10.1016/j.jembe.2010.08.020

11 Carabel S, Verísimo P, Freire J. Effects of preservatives on stable isotope analyses of four marine species. Estuar Coast Shelf Sci. 2009;82:348-350. doi:10.1016/j.ecss.2009

12 Bosley KL, Wainright SC. Effects of preservatives and acidification on the stable isotope ratios $\left({ }^{15} \mathrm{~N}:{ }^{14} \mathrm{~N},{ }^{13} \mathrm{C}:{ }^{12} \mathrm{C}\right)$ of two species of marine animals. Can J Fish. Aquat Sci. 1999;56:2181-2185. doi:10.1139/f99-153

13 Edwards MS, Turner TT, Sharp ZD. Short and long-term effects of fixation and preservation on stable isotope values $\left(\delta^{13} \mathrm{C}, \delta^{15} \mathrm{~N}, \delta^{34} \mathrm{~S}\right)$ of fluid-preserved museum specimens. Copeia. 2002;2002:1106-1112. doi:10.1643/00458511(2002)002[1106:SALTEO]2.0.CO;2

14 Lau DCP, Leung KMY, Dudgeon D. Preservation effects on $\mathrm{C} / \mathrm{N}$ ratios and stable isotope signatures of freshwater fishes and benthic macroinvertebrates. Limnol Oceanogr Methods. 2012;10:75-89. doi:10.4319/lom.2012.10.75

15 González-Bergonzoni I, Vidal N, Wang B, et al. General validation of formalin-preserved fish samples in food web studies using stable isotopes. Methods Ecol Evol. 2015;6:307314. doi:10.1111/2041-210X.12313

16 Stallings CS, Nelson JA, Rozar KL, et al. Effects of preservation methods of muscle tissue from upper-trophic level reef fishes on stable isotope values $\left(\delta^{13} \mathrm{C}\right.$ and $\left.\delta^{15} \mathrm{~N}\right)$. PeerJ. 2015;3:e874. doi:10.7717/peerj.874

17 Kim SL, Koch PL. Methods to collect, preserve, and prepare elasmobranch tissues for stable isotope analysis. Environ Biol Fish. 2011;95:53-63. doi:10.1007/s10641-0119860-9

18 Olin JA, Poulakisn GR, Stevens PW, DeAngelo JA, Fisk AT. 2014. Preservation effects on stable isotope values of archived elasmobranch fin tissue: comparisons between frozen and ethanol-stored samples. $T$ Am Fish Soc. 2014;143:1569-1576. doi:10.1080/00028487.2014.954055

19 Barrow LM, Bjorndal KA, Reich KJ. Effects of preservation method on stable carbon and nitrogen isotope values. Physiol Biochem Zool. 2008;81:688-693. doi:10.1086/588172

20 Bugoni L, McGill RAR, Furness RW. Effects of preservation methods on stable isotope signatures in bird tissues. Rapid Commun Mass Spectrom. 2008;22:2457-2462. 
doi:10.1002/rcm.3633

21 Kiszka J, Lesage V, Ridoux V. Effect of ethanol preservation on stable carbon and nitrogen isotope values in cetacean epidermis: Implication for using archived biopsy samples. Mar Mammal Sci. 2014;30:788-795. doi:10.1111/mms.12058

22 Javornik J, Hopkins III JB, Zavadlav S. al. Effects of ethanol storage and lipids on stable isotope values in a large mammalian omnivore. J Mammal. 2019;100:150-157. doi:10.1093/jmammal/gyy187

23 Oczkowski A, Thornber CS, Markham EE, Rossi R, Ziegler A, Rinehart S. Testing sample stability using four storage methods and the macroalgae Ulva and Gracilaria. Limnol Oceanogr Methods. 2015;13:9-14. doi:10.1002/lom3.10002

24 Fleming NE, Houghton JDR, Magill CL, Harrod C. Preservation methods alter stable isotope values in gelatinous zooplankton: implications for interpreting trophic ecology. Mar Biol. 2011;158:2141-2146. doi:10.1007/s00227-011-1714-7

25 Syväranta J, Martino A, Kopp D, Céréghino R, Santoul F. Freezing and chemical preservatives alter the stable isotope values of carbon and nitrogen of the Asiatic clam (Corbicula fluminea). Hydrobiologia. 2011;658:383-388. doi:10.1007/s10750-0100512-4

26 Umbricht J, Dippner JW, Fry B, et al. Correction of the isotopic composition $\left(\delta^{13} \mathrm{C}\right.$ and $\delta^{15} \mathrm{~N}$ ) of preserved Baltic and North Sea macrozoobenthos and their trophic interactions. Mar Ecol Prog Ser. 2018;595:1-13. doi:10.3354/meps 12543

27 Rennie MD, Ozersky T, Evans DO. Effects of formalin preservation on invertebrate stable isotope values over decadal time scales. Can J Zool. 2012;90:1320-1327. doi:10.1139/z2012-101

28 Krab EJ, Van Logtestijn RSP, Cornelissen JHC, Berg MP. Reservations about preservations: storage methods affect d13C signatures differently even in closely related soil fauna. Methods Ecol Evol. 2012;3:138-144. doi:10.1111/j.2041210X.2011.00126.x

29 Jesus FM, Pereira MR, Rosa CS, Moreira MZ, Sperber CF. Preservation methods alter carbon and nitrogen stable isotope values in crickets (Orthoptera: Grylloidea). PLoS ONE. 2015;10:e0137650. doi:10.1371/journal.pone.0137650

30 Feuchtmayr H, Grey J. Effect of preparation and preservation procedures on carbon and nitrogen stable isotope determinations from zooplankton. Rapid Commun. Mass Spectrom. 2003;17:2605-2610. doi:10.1002/rcm.1227 
31 Layman CA, Arrington DA, Montaña CG, Post DM. Can stable isotope ratios provide for community-wide measures of trophic structure? Ecology. 2007;88:42-28. doi:10.1890/0012-9658(2007)88[42\%3ACSIRPF]2.0.CO\%3B2

32 Cucherousset J, Villéger S. Quantifying the multiple facets of isotopic diversity: New metrics for stable isotope ecology. Ecol Indic. 2014;56:152-160. doi:10.1016/j.ecolind.2015.03.032

33 Jackson A, Inger R, Parnell AC, Bearhop S. Comparing isotopic niche widths among and within communities: SIBER - Stable Isotope Bayesian Ellipses in R. J Anim Ecol. 2011;80:595-602. doi:10.1111/j.1365-2656.2011.01806.x

34 Parnell AC, Inger R, Bearhop S, Jackson AL. Source partitioning using stable isotopes: coping with too much variation. PLoS ONE. 2010;5:e9672. doi:10.1371/journal.pone.0009672

35 Quezada-Romegialli C, Jackson AL, Hayden B, Kahilainen KK, Lopes C, Harrod C. tRophicPosition, an $\mathrm{R}$ package for the Bayesian estimation of trophic position from consumer stable isotope ratios. Methods Ecol Evol. 2018;9:1592-1599. doi:10.1111/2041-210X.13009

36 Xu J, Yang Q, Zhang M, Zhang M, Ping P, Hansson LA. Preservation effects on stable isotope ratios and consequences for the reconstruction of energetic pathways. Aquat Ecol. 2011;45:483-492. doi:10.1007/s10452-011-9369-5

37 Ribi G, Schärer R, Ochsner P. Stomach contents and size-frequency distributions of two coexisting sea star species, Astropecten aranciacus and $A$. bispinosus, with reference to competition. Mar Biol. 1977;43:181-185. doi:10.1007/BF00391266

38 Dearborn JH, Edwards KC, Fratt DB. Diet, feeding behavior, and surface morphology of the multi-armed Antarctic sea star Labidiaster annulatus (Echinodermata: Asteroidea). Mar Ecol Prog Ser. 1991;77:65-84. doi:10.3354/meps077065

39 Gale KSP, Hamel JF, Mercier A. Trophic ecology of deep-sea Asteroidea (Echinodermata) from eastern Canada. Deep-sea Res I. 2013;80:25-36. doi:10.1016/j.dsr.2013.05.016

40 Hedges JI, Stern JH. Carbon and nitrogen determinations of carbonate-containing solids. Limnol Oceanogr. 1984;29:657-663. doi:10.4319/lo.1984.29.3.0657

41 Coplen TB. Guidelines and recommended terms for expression of stable- isotope-ratio and gas-ratio measurement results. Rapid Commun Mass Spectrom. 2011,25:2538-2560. doi:10.1002/rcm.5129.

42 R Core Team. R: A language and environment for statistical computing. R Foundation for 
Statistical Computing, Vienna, Austria. http://www.R-project.org/ 2013

43 Rice WR. Analysing tables of statistical tests. Evolution. 1989;43:223-225. doi:10.1111/j.1558-5646.1989.tb04220.x

44 Reid WDK, Sweeting CJ, Wigham BD, McGill RAR, Polunin NVC. Isotopic niche variability in macroconsumers of the East Scotia Ridge (Southern Ocean) hydrothermal vents: What more can we learn from an ellipse? Mar Ecol Prog Ser. 2016;542:13-24. doi: $10.3354 /$ meps 11571

45 Von Endt DW. Spirit collections: a preliminary analysis of some organic materials found in the storage uids of mammals. Collect Forum. 1994;10:10-19.

46 Sweeting CJ, Polunin NVC, Jenings S. Tissue and fixative dependent shifts of $\delta^{13} \mathrm{C}$ and $\delta^{15} \mathrm{~N}$ in preserved ecological material. Rapid Commun Mass Spectrom. 2004;18:25872592. doi:10.1002/rcm.1661
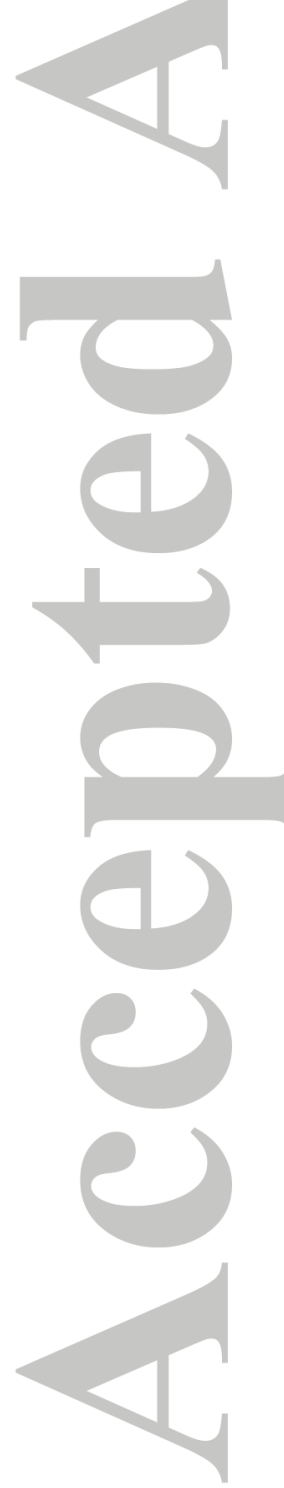
Table 1. Examples of reported shifts (mean \pm SD) of preservation methods on stable isotope ratios in aquatic animals.

\begin{tabular}{|c|c|c|c|c|c|c|}
\hline Method & Phylum & Species & $\begin{array}{l}\text { Experiment } \\
\text { duration }\end{array}$ & $\Delta \delta^{13} \mathrm{C}(\%)$ & $\Delta \delta^{15} \mathrm{~N}(\% \mathrm{)})$ & Reference \\
\hline \multirow[t]{10}{*}{ Freezing } & Cnidarians & $\begin{array}{l}\text { Aurelia } \\
\text { aurita }\end{array}$ & 6 months & $\begin{array}{l}\text { Not } \\
\text { significant }\end{array}$ & $\downarrow-2.1$ & 24 \\
\hline & Mollusks & $\begin{array}{l}\text { Corbicula } \\
\text { fluminea }\end{array}$ & 12 months & $\uparrow+2.1 \pm 0.3$ & $\uparrow+1.0 \pm 0.3$ & 25 \\
\hline & & $\begin{array}{l}\text { Octopus } \\
\text { vulgaris }\end{array}$ & 12 weeks & $\begin{array}{l}\text { Not } \\
\text { significant }\end{array}$ & $\begin{array}{l}\text { Not } \\
\text { significant }\end{array}$ & 8 \\
\hline & Crustaceans & $\begin{array}{l}\text { Bulk } \\
\text { zooplankton }\end{array}$ & 4 days & $\downarrow-0.9$ & $\uparrow+0.6$ & 30 \\
\hline & Echinoderms & $\begin{array}{l}\text { Marthasteria } \\
\text { s glacialis }\end{array}$ & 24 months & $\begin{array}{l}\text { Not } \\
\text { significant }\end{array}$ & $\begin{array}{l}\text { Not } \\
\text { significant }\end{array}$ & This study \\
\hline & Teleosts & $\begin{array}{l}\text { Argiosomus } \\
\text { hololepidotu } \\
\text { s }\end{array}$ & 12 weeks & $\begin{array}{l}\text { Not } \\
\text { significant }\end{array}$ & $\begin{array}{l}\text { Not } \\
\text { significant }\end{array}$ & 8 \\
\hline & & $\begin{array}{l}\text { Various } \\
\text { species }\end{array}$ & 1 month & $\begin{array}{l}\text { Not } \\
\text { significant }\end{array}$ & $\begin{array}{l}\text { Not } \\
\text { significant }\end{array}$ & 16 \\
\hline & Mollusks & $\begin{array}{l}\text { Octopus } \\
\text { vulgaris }\end{array}$ & 12 weeks & $\begin{array}{l}\text { Not } \\
\text { significant }\end{array}$ & $\begin{array}{l}\text { Not } \\
\text { significant }\end{array}$ & 8 \\
\hline & Echinoderms & $\begin{array}{l}\text { Marthasteria } \\
\text { s glacialis }\end{array}$ & 24 months & $\begin{array}{l}\text { Not } \\
\text { significant }\end{array}$ & $\begin{array}{l}\text { Not } \\
\text { significant }\end{array}$ & This study \\
\hline & Teleosts & $\begin{array}{l}\text { Argiosomus } \\
\text { hololepidotu }\end{array}$ & 12 weeks & $\begin{array}{l}\text { Not } \\
\text { significant }\end{array}$ & $\begin{array}{l}\text { Not } \\
\text { significant }\end{array}$ & 8 \\
\hline
\end{tabular}

This article is protected by copyright. All rights reserved. 


\begin{tabular}{|c|c|c|c|c|c|c|}
\hline & & $\begin{array}{l}\text { Various } \\
\text { species }\end{array}$ & 625 days & $\begin{array}{l}\text { Not } \\
\text { significant }\end{array}$ & $\begin{array}{l}\text { Not } \\
\text { significant }\end{array}$ & 36 \\
\hline \multirow{4}{*}{$\begin{array}{l}\text { Formaldehy } \\
\text { de }\end{array}$} & Polychaetes & $\begin{array}{l}\text { Chirimia } \\
\text { biceps }\end{array}$ & 12 months & $\downarrow-4.1$ & $\begin{array}{l}\text { Not } \\
\text { significant }\end{array}$ & 10 \\
\hline & & $\begin{array}{l}\text { Magelona } \\
\text { spp. }\end{array}$ & 18 weeks & $\downarrow-2.1$ & $\downarrow-1.0$ & 26 \\
\hline & & $\begin{array}{l}\text { Nephtys } \\
\text { hystricis }\end{array}$ & 12 months & $\downarrow-3.1$ & $\begin{array}{l}\text { Not } \\
\text { significant }\end{array}$ & 10 \\
\hline & Sipunculid & $\begin{array}{l}\text { Sipunculus } \\
\text { norvegicus }\end{array}$ & 12 months & $\downarrow-3.5$ & $\begin{array}{l}\text { Not } \\
\text { significant }\end{array}$ & 10 \\
\hline & Mollusks & $\begin{array}{l}\text { Corbicula } \\
\text { fluminea }\end{array}$ & 12 months & $\uparrow+2.2 \pm 0.3$ & $\uparrow+1.0 \pm 0.2$ & 29 \\
\hline & & $\begin{array}{l}\text { Abra } \\
\text { longicalus }\end{array}$ & 12 months & $\downarrow-2.1$ & $\begin{array}{l}\text { Not } \\
\text { significant }\end{array}$ & 10 \\
\hline & & $\begin{array}{l}\text { Octopus } \\
\text { vulgaris }\end{array}$ & 12 weeks & $\downarrow-0.3 \pm 0.1$ & $\begin{array}{l}\text { Not } \\
\text { significant }\end{array}$ & 8 \\
\hline & & $\begin{array}{l}\text { Mya } \\
\text { arenaria }\end{array}$ & 18 weeks & $\downarrow-1.5 \pm 0.8$ & $\begin{array}{l}\text { Not } \\
\text { significant }\end{array}$ & 26 \\
\hline & & $\begin{array}{l}\text { Tellina } \\
\text { fabula }\end{array}$ & 18 weeks & $\downarrow-2.7 \pm 0.3$ & $\begin{array}{l}\text { Not } \\
\text { significant }\end{array}$ & 26 \\
\hline & Crustaceans & $\begin{array}{l}\text { Bulk } \\
\text { zooplankton }\end{array}$ & 4 days & $\uparrow+1.1$ & $\uparrow+0.8$ & 30 \\
\hline & Echinoderms & $\begin{array}{l}\text { Molpadia } \\
\text { musculus }\end{array}$ & 12 months & $\begin{array}{l}\uparrow \quad+3.9 \quad(6 \\
\text { months }) \\
\downarrow \quad-2.6 \quad(12\end{array}$ & $\begin{array}{l}\text { Not } \\
\text { significant }\end{array}$ & 10 \\
\hline
\end{tabular}

This article is protected by copyright. All rights reserved. 


\begin{tabular}{|c|c|c|c|c|c|c|}
\hline & & & & months) & & \\
\hline & & $\begin{array}{l}\text { Marthasteria } \\
\text { s glacialis }\end{array}$ & 24 months & $\downarrow-0.8 \pm 0.5$ & $\begin{array}{l}\text { Not } \\
\text { significant }\end{array}$ & This study \\
\hline & Teleosts & $\begin{array}{l}\text { Argiosomus } \\
\text { hololepidotu } \\
\text { s }\end{array}$ & 12 weeks & $\downarrow-0.5 \pm 0.1$ & $\begin{array}{l}\text { Not } \\
\text { significant }\end{array}$ & 8 \\
\hline & & $\begin{array}{l}\text { Various } \\
\text { species }\end{array}$ & 625 days & $\downarrow-1.0$ & $\begin{array}{l}\text { Not } \\
\text { significant }\end{array}$ & 36 \\
\hline Ethanol & Cnidarians & $\begin{array}{l}\text { Aurelia } \\
\text { aurita }\end{array}$ & 6 months & $\begin{array}{l}\text { Not } \\
\text { significant }\end{array}$ & $\downarrow-2.4$ & 24 \\
\hline & Polychaetes & $\begin{array}{l}\text { Chirimia } \\
\text { biceps }\end{array}$ & 12 months & $\begin{array}{l}\text { Not } \\
\text { significant }\end{array}$ & $\begin{array}{l}\text { Not } \\
\text { significant }\end{array}$ & 10 \\
\hline & & $\begin{array}{l}\text { Magelona } \\
\text { spp. }\end{array}$ & 18 weeks & $\uparrow+1.4 \pm 0.2$ & $\uparrow+0.9 \pm 0.0$ & 26 \\
\hline & & $\begin{array}{l}\text { Nephtys } \\
\text { hystricis }\end{array}$ & 12 months & $\begin{array}{l}\text { Not } \\
\text { significant }\end{array}$ & $\begin{array}{l}\text { Not } \\
\text { significant }\end{array}$ & 10 \\
\hline & Sipunculid & $\begin{array}{l}\text { Sipunculus } \\
\text { norvegicus }\end{array}$ & 12 months & $\begin{array}{l}\text { Not } \\
\text { significant }\end{array}$ & $\downarrow-1.7$ & 10 \\
\hline & Mollusks & $\begin{array}{l}\text { Abra } \\
\text { longicalus }\end{array}$ & 12 months & $\begin{array}{l}\text { Not } \\
\text { significant }\end{array}$ & $\begin{array}{l}\text { Not } \\
\text { significant }\end{array}$ & 10 \\
\hline & & $\begin{array}{l}\text { Corbicula } \\
\text { fluminea }\end{array}$ & 12 months & $\uparrow+1.3 \pm 0.3$ & $\uparrow+0.9 \pm 0.2$ & 25 \\
\hline & & $\begin{array}{l}\text { Octopus } \\
\text { vulgaris }\end{array}$ & 12 weeks & $\uparrow+1.6 \pm 0.3$ & $\begin{array}{l}\text { Not } \\
\text { significant }\end{array}$ & 8 \\
\hline & & $\begin{array}{l}\text { Mya } \\
\text { arenaria }\end{array}$ & 18 weeks & $\downarrow-1.4 \pm 6.5$ & $\begin{array}{l}\text { Not } \\
\text { significant }\end{array}$ & 26 \\
\hline
\end{tabular}

This article is protected by copyright. All rights reserved. 


\begin{tabular}{|c|c|c|c|c|c|}
\hline & $\begin{array}{l}\text { Tellina } \\
\text { fabula }\end{array}$ & 18 weeks & $\uparrow+0.8$ & $\uparrow+0.6$ & 26 \\
\hline Crustaceans & $\begin{array}{l}\text { Bulk } \\
\text { zooplankton }\end{array}$ & 4 days & $\begin{array}{l}\text { Not } \\
\text { significant }\end{array}$ & $\uparrow+0.8$ & 30 \\
\hline Echinoderms & $\begin{array}{l}\text { Molpadia } \\
\text { musculus }\end{array}$ & 12 months & $\uparrow+3.6$ & $\begin{array}{l}\text { Not } \\
\text { significant }\end{array}$ & 10 \\
\hline & $\begin{array}{l}\text { Marthasteria } \\
\text { s glacialis }\end{array}$ & 24 months & $\uparrow+0.6 \pm 0.5$ & $\begin{array}{l}\text { Not } \\
\text { significant }\end{array}$ & This study \\
\hline Teleosts & $\begin{array}{l}\text { Argiosomus } \\
\text { hololepidotu } \\
\text { s }\end{array}$ & 12 weeks & $\uparrow+0.7 \pm 0.2$ & $\begin{array}{l}\text { Not } \\
\text { significant }\end{array}$ & 8 \\
\hline & $\begin{array}{l}\text { Various } \\
\text { species }\end{array}$ & 625 days & $\uparrow+0.7$ & $\uparrow+0.4$ & 36 \\
\hline & $\begin{array}{l}\text { Various } \\
\text { species }\end{array}$ & 1 month & $\uparrow+0.4 \pm 0.4$ & $\uparrow+0.6 \pm 0.4$ & 16 \\
\hline
\end{tabular}

This article is protected by copyright. All rights reserved. 
Table 2. Summary of the influence of preservation methods on $\delta^{13} \mathrm{C}, \delta^{15} \mathrm{~N}$ and $\delta^{34} \mathrm{~S}$ values, $\mathrm{C} / \mathrm{N}$ ratios, and Bayesian estimation standard ellipse area $\left(\mathrm{SEA}_{\mathrm{B}}\right)$ computed with $\delta^{13} \mathrm{C}$ and $\delta^{15} \mathrm{~N}$ values and with $\delta^{13} \mathrm{C}$ and $\delta^{34} \mathrm{~S}$ values in Marthasterias glacialis tissues preserved for 24 months.

\begin{tabular}{|c|c|c|c|c|c|c|}
\hline & $\delta^{13} \mathrm{C}(\% 0)$ & $\delta^{15} \mathrm{~N}(\%)$ & $\delta^{34} \mathrm{~S}(\% 0)$ & $\mathrm{C} / \mathrm{N}$ & $\begin{array}{l}\text { SEA }_{B} \text { with } \\
\delta^{13} \mathrm{C} \\
\delta^{15} \mathrm{~N}\end{array}$ & $\begin{array}{l}\text { SEA }_{B} \\
\delta^{13} \mathrm{C} \text { and } \delta^{34} \mathrm{~S}\end{array}$ \\
\hline Freezing & $\begin{array}{l}\text { Not } \\
\text { significant }\end{array}$ & $\begin{array}{l}\text { Not } \\
\text { significant }\end{array}$ & Inconsistent & $\begin{array}{l}\text { Not } \\
\text { significant }\end{array}$ & $\begin{array}{l}\text { Not } \\
\text { significant }\end{array}$ & $\begin{array}{l}\text { Not } \\
\text { significant }\end{array}$ \\
\hline Drying & $\begin{array}{l}\text { Not } \\
\text { significant }\end{array}$ & Inconsistent & Inconsistent & $\begin{array}{l}\text { Not } \\
\text { significant }\end{array}$ & Inconsistent & $\begin{array}{l}\text { Not } \\
\text { significant }\end{array}$ \\
\hline $\begin{array}{l}\text { Formaldehy } \\
\text { de }\end{array}$ & $\begin{array}{l}\downarrow-0.8 \pm 0.5 \\
\% \text { o }\end{array}$ & $\begin{array}{l}\text { Not } \\
\text { significant }\end{array}$ & $\begin{array}{l}\downarrow-1.5 \pm 1.2 \\
\%\end{array}$ & Inconsistent & $\begin{array}{l}\text { Not } \\
\text { significant }\end{array}$ & $\begin{array}{l}\text { Not } \\
\text { significant }\end{array}$ \\
\hline Ethanol & $\begin{array}{l}\uparrow+0.6 \pm 0.5 \\
\% \text { o }\end{array}$ & $\begin{array}{l}\text { Not } \\
\text { significant }\end{array}$ & $\begin{array}{l}\downarrow-0.7 \pm 1.0 \\
\% *\end{array}$ & $\begin{array}{lll}\uparrow & 0.22 \quad \pm \\
0.10 & \end{array}$ & Inconsistent & $\begin{array}{l}\text { Not } \\
\text { significant }\end{array}$ \\
\hline
\end{tabular}

* Significant difference only between samples at $\mathrm{T}_{0}$ and preserved samples at 24 months. 
Fig. 1, top of the figure
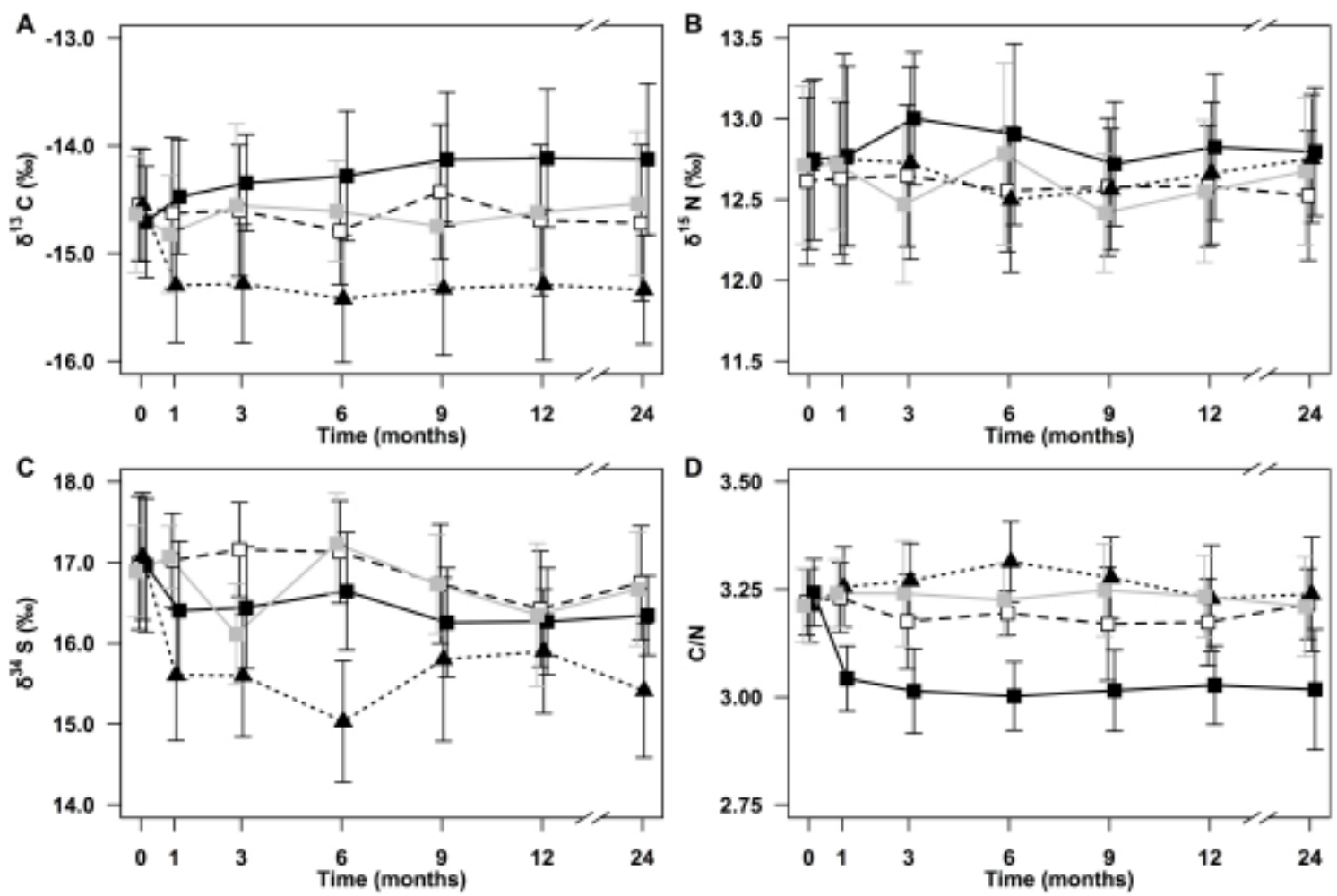

Figure 1. Evolution of mean $\pm \mathrm{SD}$ of A) $\delta^{13} \mathrm{C}$, values B) $\delta^{15} \mathrm{~N}$ values, C) $\delta^{34} \mathrm{~S}$ values and D) $\mathrm{C} / \mathrm{N}$ ratios in Marthasterias glacialis tissues stored frozen (white squares and dashed lines), dried (grey squares and lines), in formaldehyde (black triangles and dotted lines) or in ethanol (black squares and full lines) for 24 months.

This article is protected by copyright. All rights reserved. 
Fig. 2, top of the figure
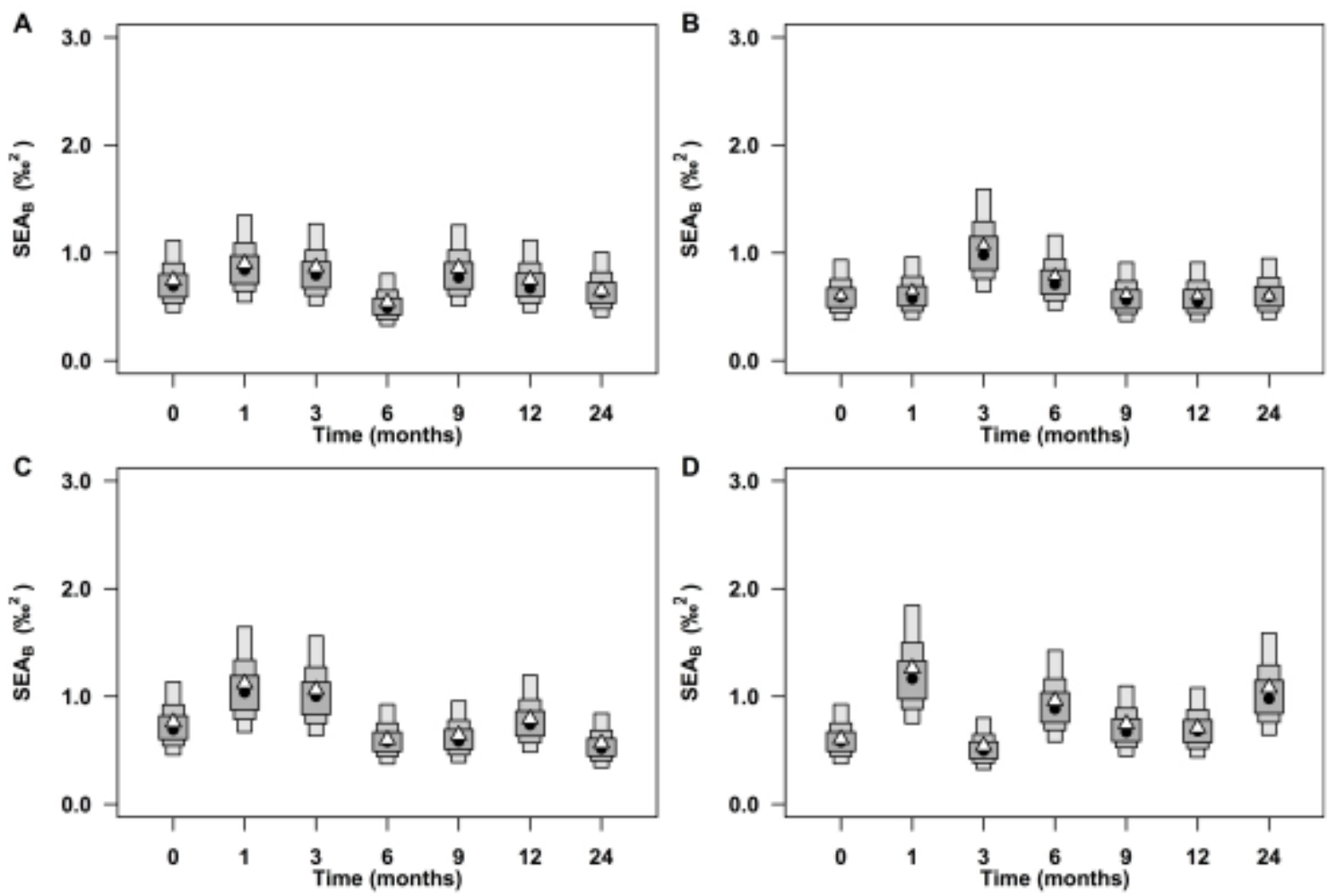

Figure 2. SIBER density plots depicting evolution of standard ellipse areas computed with $\delta^{13} \mathrm{C}$ and $\delta^{15} \mathrm{~N}$ values and estimated with Bayesian analysis, as well as standard ellipse areas corrected for sample size, in Marthasterias glacialis tissues stored A) frozen, B) dried, C) in formaldehyde or D) in ethanol for 24 months. Black dots are the modes. Shaded boxes represent the $50 \%, 75 \%$ and $95 \%$ confidence intervals, from dark to light grey. White triangles are standard ellipse areas corrected for sample size. 
Fig. 3, top of the figure
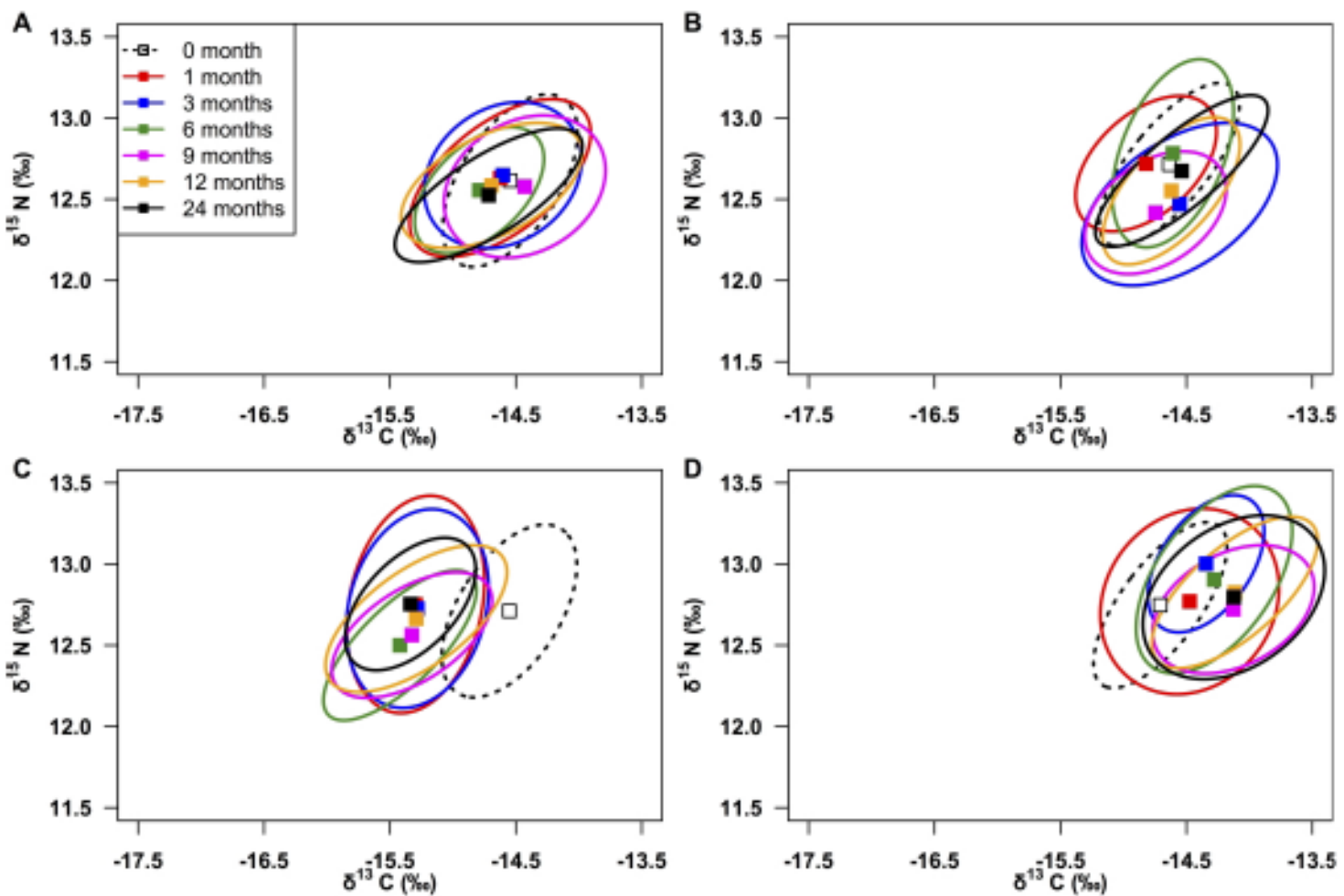

Figure 3 .

Figure 3. Evolution of mean stable isotope ratios and isotopic niche computed with $\delta^{13} \mathrm{C}$ and $\delta^{15} \mathrm{~N}$ values in Marthasterias glacialis tissues stored A) frozen, B) dried, C) in formaldehyde or D) in ethanol for 24 months.

This article is protected by copyright. All rights reserved. 
Fig. 4 , top of the figure
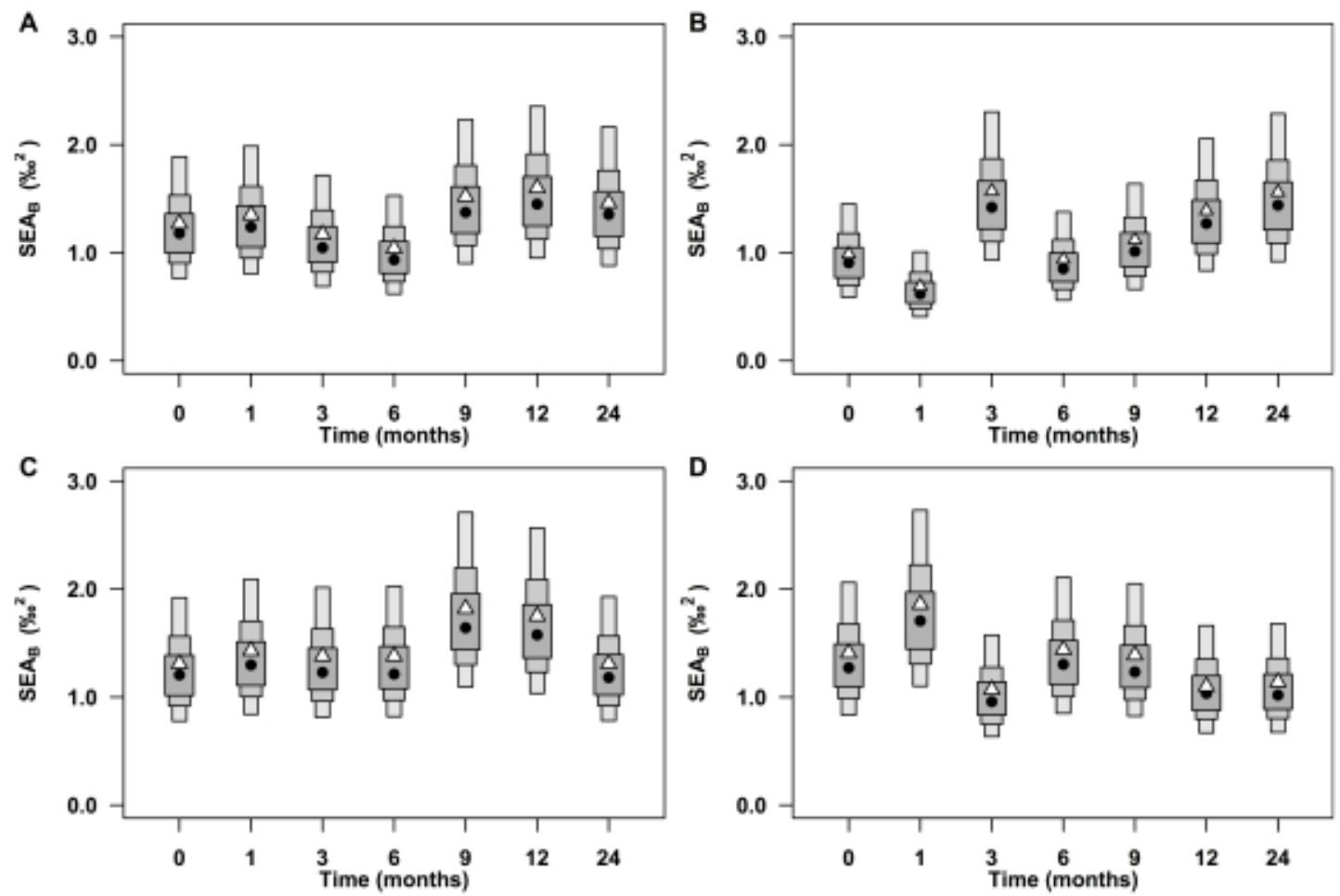

Figure 4. SIBER density plots depicting evolution of standard ellipse area computed with $\delta^{13} \mathrm{C}$ and $\delta^{34} \mathrm{~S}$ values and estimated with Bayesian analysis, as well as standard ellipse areas corrected for sample size, in Marthasterias glacialis tissues stored A) frozen, B) dried, C) in formaldehyde or D) in ethanol for 24 months. Black dots are the modes. Shaded boxes represent the $50 \%, 75 \%$ and $95 \%$ confidence intervals, from dark to light grey. White triangles are sample size corrected standard ellipse areas corrected for sample size. 
Fig. 5, top of the figure
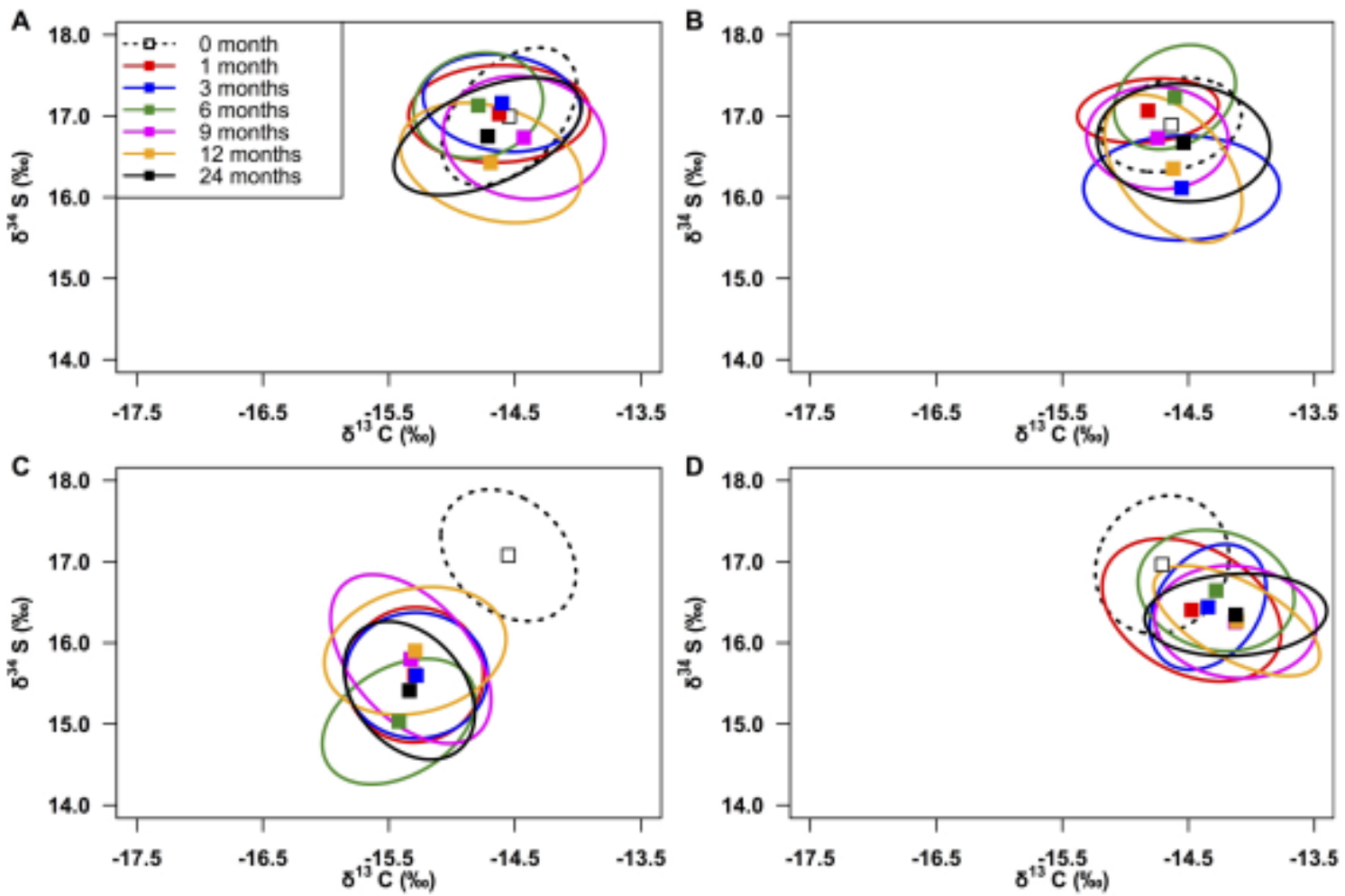

Figure 5. Evolution of mean stable isotope ratios and isotopic niche computed with $\delta^{13} \mathrm{C}$ and $\delta^{34} \mathrm{~S}$ values in Marthasterias glacialis tissues stored A) frozen, B) dried, C) in formaldehyde or D) in ethanol during 24 months.

This article is protected by copyright. All rights reserved. 